\title{
Tunisian EFL Teachers' Beliefs and Perceptions About Oral Corrective Feedback
}

\author{
Ounis Tesnim \\ English Department, Faculty of Letters and Humanities of Sfax, University of Sfax, Sfax, Tunisia \\ Email address: \\ otesnim@yahoo.fr

\section{To cite this article:} \\ Ounis Tesnim. Tunisian EFL Teachers' Beliefs and Perceptions About Oral Corrective Feedback. Communication and Linguistics Studies. \\ Vol. 5, No. 2, 2019, pp. 45-53. doi: 10.11648/j.cls.20190502.12
}

Received: May 20, 2019; Accepted: June 17, 2019; Published: June 29, 2019

\begin{abstract}
The objective of the present research paper is to describe the beliefs and the perceptions of Tunisian EFL teachers regarding the nature and the purpose of oral corrective feedback (OCF) used in teaching speaking. The method relies on the use of a questionnaire survey which is made up of seven items. 20 EFL teachers participated in this study and they were invited to fill in the questionnaire which seeks to elicit their opinions and preferences concerning the particular type of feedback they deliver as a response to their students' spoken errors. The results of the study found out that EFL teachers hold positive attitudes towards OCF, as the majority of the informants seem to embrace the benefits of OCF and its importance in the language learning process. However, the findings show that the respondents' opinions concerning the timing of using OCF, its impact on developing speaking skills and on learners' feelings and emotions vary significantly. The results also display some discrepancy in teachers' responses to some items and reveal that the dominant types of OCF used in teaching speaking were explicit correction, recasts and elicitation.
\end{abstract}

Keywords: Oral Corrective Feedback, Teachers' Perceptions, Speaking, Types of Corrective Feedback

\section{Introduction}

According to Hattie and Timperley, feedback generally denotes any type of "information provided by an agent (e.g., teacher, peer, book, parent, self, experience) regarding aspects of one's performance or understanding." ([1], p.) It has gained considerable interest among researchers who tried to define the concept and to outline its significant importance in the field of language learning in particular and education in general. Crystal defined feedback as "the process whereby the sender of a message obtains a reaction from the receiver which enables a check to be made on the efficiency of the communication" ([2], p. 187). In order to emphasize the role of feedback in the process of learning the target language, Crystal confirmed that "speakers are able to monitor their own performance (both by self-observation, and by observing the responsesignals of others) "([2], p. 187) thanks to feedback delivered during oral production and interactions. Likewise, Leahy, Lyon, Thompson, \& William viewed feedback as a necessary technique used by teachers to facilitate the noticing of ill-formed or erroneous utterances of their learners [3]. As such, in the classroom context, teachers are at the heart core of feedback delivery since they are the ones who provide corrective feedback depending on different variables such as the appropriate timing, the type of the activity, the type of feedback strategy, the type of the error and the ways convenient to a given context. Therefore, it is assumed that teachers' conceptions and perceptions regarding the objectives and the nature of feedback will certainly influence their classroom decisions and practices (when and how to provide feedback) which will have great influence on the learners $[1,4,5]$. The present research paper seeks to explore and understand the various attitudes and opinions that teachers may hold concerning the concept of Corrective feedback (CF) conducted during oral work.

\section{Theoretical framework}

\subsection{Understanding the Concept of Oral Corrective Feedback (OCF)}

The concept of feedback has been among the most 
significant issue in the field of education, and language education. Although researchers have proposed various definitions for the concept of CF across decades, the central idea is practically shared. It is widely perceived as any form of information provided by an agent (e.g., teacher, peer, book, parent, and self experience) regarding aspects of one's performance or understanding, for instance, CF is described as "any reaction of the teacher which clearly transforms, disapprovingly refers to, or demands improvement of the learner utterance" ([1-6], p. 51). According to Schegloff et al., CF refers to "the replacement of error or mistake by what is correct" ([7], p. 363). Lyster, Saito and Sato tend to consider $\mathrm{CF}$ as 'responses to learner utterances containing an error" and as a "complex phenomenon with several functions" [8]. Similarly, according to Lightbown and Spada, CF serves to warn speakers that their use of the target language is erroneous [9]. For instance, when a language learner says, 'He go to school every day', corrective feedback can be explicit, 'no, you should say goes, not go' or implicit 'yes he goes to school every day', and may or may not include metalinguistic information, for example, 'Don't forget to make the verb agree with the subject' ([9], p. 171172). As such, it is recognized as "any indication to the learners that their use of the target language is incorrect" ([9], p. 171). Similarly, Russell and Spada argue that "any feedback provided to a learner, from any source, that contains evidence of learner error of language form" ([10], p. 134) is considered as CF. Ellis et al. perceive that CF denotes any kind of response directed to repair learner's erroneous utterance (i.e. linguistically deviant). These different forms of responses might basically include ([11], p. 28):

(1) An indication that an error has been committed.

(2) Provision of the correct target language form.

(3) Metalinguistic information about the nature of the error, or any combination of these.

CF has been classified into two groups such as explicit feedback and implicit feedback or negative feedback and positive feedback [11-13]. According to Schachter, corrective feedback, negative evidence, and negative feedback are three terms used respectively in the fields of language teaching, language acquisition, and cognitive psychology [14]. Negative feedback indicates that there is a problem in the learners' utterances. As such, it refers to any type of information that alerts the learners to what is unacceptable in their utterances [15]. Corrective feedback refers to the various forms of teachers' responses to learners' utterances including an error. The responses can be other-initiated repairs, in the sense that they point to an occurring error and supply the correct target language form. They can also include metalinguistic information about the nature of the error. Feedback could be explicit (e.g., grammatical explanation or overt error correction) or implicit. Implicit correction includes: Confirmation checks, repetitions, recasts, clarification requests, silence, and even facial expressions that express confusion [14].

Therefore, OCF can be presented in different forms such as verbal expressions or facial signals. In the classroom context, it denotes the different "comments or information learners receive on the success of a learning task, either from the teacher or from other learners" ([16], p. 137). In Chaudron's view, treatment of error may basically refer to "any teacher behavior following an error that minimally attempts to inform the learner of the fact of error" ([6]: 66). Besides, it is characterized by imprecision and inconsistency. While the latter happens when the teacher respond variably to the same error made by different students in the same class, correcting some students and ignoring others, imprecision occurs when the teacher uses the same overt behavior (e.g. repetition) both to indicate that an error has been made and to reinforce a correct response, as such it urges the learner into more effort leading to a greater depth of processing [17]. In this context, it may reflect teachers' attempts to cater for individual differences among their students [18].

Moreover, several researchers and scholars have outlined the benefits of endorsing effective CF inside the classroom setting. CF is viewed as a means of fostering learner motivation and ensuring linguistic accuracy in both behaviorist and communicative approaches to language teaching [19]. In the same vein, CF contributes to the development of knowledge and skill acquisition [20]. Interactional feedback is "an important source of information for learners and it provides them with information about the success (or, more likely, lack of success) of their utterances and gives additional opportunities to focus on production and comprehension" ([21], p: 329). Effective feedback should elicit information about three aspects: (1) The quality of the current performance with regard to the desired goal, (2) The quality of the desired performance, and (3) The question of how to close the gap between present and desired performance [22].

\subsection{Lyster and Ranta's Taxonomy (1997)}

According to Lyster and Ranta's Taxonomy, oral feedback types are made up of the following six types [23]:

1. Explicit correction: It consists of a direct and clear indication of the ill-formed utterances. It is "the explicit provision of the correct form" where the teacher "clearly indicates that what the student ha [s] said [is] incorrect (e.g. "Oh you mean", "You should say")."

2. Recasts: It involves repeating the ill-formed utterance in a correct way. It is "the teacher's reformulation of all or part of the student's utterance, minus the error".

3. Clarification requests: This type informs the student that his-her utterance has been misunderstood or illformed and as a result a repetition or a reformulation is requisite. It "indicates to students either that their utterance has been misunderstood by the teacher or that the utterance is ill-formed in some way".

4. Metalinguistic feedback $(M F)$ : It takes the form of "comments, information or questions related to the well-form0edness of the students' utterance, without explicitly providing the correct form."

5. Elicitation: The teacher explicitly asks questions that 
aim at eliciting the correct form from the learner. "Teachers elicit completion of their own utterance by strategically pausing to allow students to fill in the blank."

6. Repetition: It is the teacher's repetition, in isolation, of the learner's incorrect utterance (usually with adjusted intonation).

\subsection{Teachers' Beliefs and Perceptions}

The investigation of teachers' perceptions and its relation to teachers' practices is an important field of study. According to Borg, teachers' cognition refers to "an amalgam of what teachers know, believe, and think, which has been traditionally described by constructs such as knowledge, belief, attitude, value, perception, and rationale... It embraces the complexity of teacher's mental lives" ([24], p. 49). In fact, the power of teachers' beliefs and perceptions, including their intentions, attitudes, values, expectations, and assumptions about teaching and learning, to influence and to shape their classroom practices and behaviors have been discussed by many scholars [25-27]. It is believed that teachers' beliefs contribute significantly to their actions [2830]. Teachers "shape the curriculum according to their own beliefs, teach their own personal values, through the implicit curriculum, and operate their classroom in accordance with their own particular definitions of teaching and learning" ([31], p. 70).

Researchers resorted to different research instruments in order to explore teachers' beliefs and perceptions, they used questionnaires, inventories, and interviews and they have discussed teachers' beliefs in accordance to various sets or areas [32-36]. Teachers' beliefs consist of three parts: (1) beliefs about language learning, (2) beliefs about learners, and (3) beliefs about themselves as language teachers [37]. They were also investigated in four areas which are: (1) general beliefs about child development, (2) general beliefs about language learning, (3) specific beliefs about teaching English to children, and (4) self efficacy and expectations [36]. Researchers have also outlined the existence of several contextual factors that may intervene to shape the beliefs and attitudes of EFL teachers. These factors include curriculum mandates, availability of resources and the instructional setting [38-40].

In this study, it is assumed that EFL teachers' beliefs and perceptions about the nature and the purpose of oral corrective feedback will probably influence both the ways and the quality of feedback realization. However, it seems that little research was devoted to understand and to examine teachers' perceptions regarding the notion of feedback, as the majority of studies were concerned with enacted classroom practices [41, 42]. The present research contributes to this field by exploring, presenting and interpreting data obtained from a questionnaire survey that seeks to elicit Tunisian teachers' beliefs and perceptions of oral corrective feedback. These perceptions could be mapped to practices of feedback inside the classroom context.

\section{Methodology}

\subsection{Research Questions}

The present research study addresses the following question:

What are EFL teachers' perceptions regarding the implementation of oral corrective feedback during speaking activities?

\subsection{Research Objectives}

The current study seeks:

A. To investigate the attitudes and beliefs of EFL teachers about the ways of conducting oral corrective feedback strategies in order to consolidate EFL learners' speaking skills.

B. To find out the most frequently used oral corrective feedback strategy during oral work.

C. To account for the possible factors that influence EFL teachers' choices of particular oral corrective feedback types.

D. To illustrate how EFL learners feel when they receive oral corrective feedback.

E. To try to assess the efficiency of oral corrective feedback in the development of learners' speaking skills.

\subsection{Participants}

It is necessary to choose a sample which actually belongs to the population that the researcher is concerned with. In fact, to guarantee validity and reliability, choosing a representative sample from the appropriate population is very rewarding. A group of 20 EFL teachers participated in the study. They were asked to answer a questionnaire survey.

\subsection{Research Instrument}

The questionnaire is the adequate data collection tool used to collect data on EFL teachers' perceptions, opinions, beliefs and preferences regarding OCF delivery as a reaction to students' spoken errors. It included a set of items that mainly focused on whether learner's errors should be corrected or not; by whom spoken errors should be corrected; the timing of implementing OCF; the types of spoken errors that should be corrected; the frequency in which teachers tend to correct certain aspects of the language; and the perceived effectiveness of OCF on promoting speaking skills. The questionnaire consists of seven close questions: the first five questions used a 5-point Likert scale ranging from 1 (Completely disagree) to 5 (Completely agree), and the last two questions used a 5-point Likert scale ranging from 1 (Never) to 5 (Always).

\subsection{Procedure}

To achieve the research objectives and to provide an answer to the research question mentioned above, this study basically relies on the use of a quantitative method which 
allowed the researcher to measure the informants' perceptions and preferences and to gauge the impact of teachers' OCF on the development of learners' speaking skills. A questionnaire was handed to 20 EFL teachers who were directly contacted. It took roughly 18 days to distribute the questionnaire, in person, to the teachers who were very cooperative to fill it in. It is to be noted that some teachers completed the questionnaire during the break and they handed it back to the researcher while others preferred to give it back at their time convenience. The respondents were invited to fill in this questionnaire and were chiefly encouraged to express very freely and openly their opinions and preferences concerning the particular type of feedback they deliver as a response to their students' spoken errors. The questionnaire included a series of questions that were an opportunity for the respondents to think about and express their views about the ways of performing OCF and its impact on learners' speaking skills. To analyze the collected data, descriptive statistics were used with SPSS v. 18 (Statistical Package for the Social Sciences).

\section{Findings and Discussion}

\subsection{EFL Teachers' Reactions in Response to Their Learners' Spoken Errors}

The results of the first question of the questionnaire depict the various reactions that EFL teachers may resort to as a response to the spoken errors committed by their students.

Table 1. EFL Teachers' reactions in response to their learners' spoken errors.

\begin{tabular}{|c|c|c|c|c|c|}
\hline & $\begin{array}{l}\text { Completely } \\
\text { disagree }\end{array}$ & Disagree & $\begin{array}{l}\text { Partially } \\
\text { agree }\end{array}$ & agree & $\begin{array}{l}\text { Completely } \\
\text { agree }\end{array}$ \\
\hline To ignore the error. & $100 \%$ & 0 & 0 & 0 & 0 \\
\hline To indicate the error immediately and provide the correct form explicitly. & 0 & 0 & $15 \%$ & $60 \%$ & $25 \%$ \\
\hline To indicate the error but give the learner a chance to correct it by himself & 0 & 0 & $10 \%$ & $70 \%$ & $20 \%$ \\
\hline To identify the error and let another student correct it. & 0 & $25 \%$ & $50 \%$ & $25 \%$ & 0 \\
\hline
\end{tabular}

Table 1 reveals that all the informants (100\%) "completely disagree" about ignoring students' errors. This result implies that EFL teachers seem to agree about the importance of error correction in the process of language learning. More than half of the informants chose the option "agree" to express their tendency to "indicate the error and provide the correct form immediately". It could indicate that EFL teachers preferred immediate oral correction. This tendency, however, shows that the informants are not aware of the negative impact of immediate CF during speaking activities, such as interrupting the flow of the communication, creating anxiety and demotivating students [43].

The overwhelming majority of informants perceive that it is useful to indicate the error but give the learner the opportunity to correct it by himself ( $70 \%$ chose "agree"). In this case, EFL teachers seem to be aware of the importance of learners' self-correction which is necessary to strengthen learners' autonomy in the classroom context [44]. Half of the informants opted for "partially agree" to indicate that they favor "to identify the error and let another student give the correct answer". This result implies that EFL teachers seem to view "peer correction" as a relative strategy that depends on the communicative situation, the context and the type of the activity.

\subsection{The Prevailing Different Views Regarding the Impact and the Role of OCF in the Language Learning Process}

The informants' responses towards the impact and the role of OCF in the language learning process are classified into different views, as shown in the table below.

Table 2. The prevailing different views regarding the impact and the role of OCF.

\begin{tabular}{|c|c|c|c|c|c|}
\hline & $\begin{array}{l}\text { Completely } \\
\text { disagree }\end{array}$ & Disagree & $\begin{array}{l}\text { Partially } \\
\text { agree }\end{array}$ & Agree & $\begin{array}{l}\text { Completely } \\
\text { agree }\end{array}$ \\
\hline OCF promotes learners' awareness of and familiarity with their errors & 0 & 0 & $50 \%$ & $50 \%$ & 0 \\
\hline OCF improves learners’ accuracy & 0 & 0 & $20 \%$ & $80 \%$ & 0 \\
\hline OCF improves learners' speaking performance & 0 & 0 & $60 \%$ & $40 \%$ & 0 \\
\hline OCF promotes learners' fluency & 0 & $10 \%$ & $20 \%$ & $70 \%$ & 0 \\
\hline
\end{tabular}

Table 2 reveals that a large number of EFL teachers consider OCF as important in the language learning process for various reasons. Half of the informants $(50 \%)$ agree that OCF promotes learners' awareness of their errors. This view implies that the learners become aware of errors they committed because the teacher provided them with the necessary OCF strategies. So, once students become familiar with the error types, it will be easier for them to avoid the same error in their next practices. This perception echoes the view supported by Kosar and Bedir who maintained that
OCF facilitates learners' decision to avoid the same type of error through selecting the appropriate strategy in their future speaking performance [45].

Furthermore, the results show that the majority of the informants $(80 \%)$ agree upon the importance of OCF in improving learners' accuracy. Therefore, the teachers seem to adhere to the view that OCF helps in making students successful in learning the language through instructing them on the appropriate use of words and vocabulary as well as the correct use of linguistic structure. Similarly, Sarwar believed 
that someone who succeeds in learning the target language is usually seen from the way he talks - the more accurate his speaking is, the more visible his successful can be [46].

An important proportion of the informants $(70 \%)$ agree on the role of OCF in fostering the students' fluency. This view is in parallel with the idea that OCF has a positive impact on language learning. However, 2 out of 20 participants (10\%) believe that OCF does not have a significant role in gaining fluency. But the majority of the informants seem to agree upon the benefits of OCF and its impact on the EFL students. So, they tend to consider OCF to be necessary to develop both accuracy and fluency. Also, the majority of these instructors select the option "agree" to show that they believe in the role of OCF in promoting learner' speaking skills. Their view confirms that as a result to the various ways of their teachers' OCF, students become more confident, motivated and willing to communicate and convey their thoughts and emotions and thus enjoy their speaking performances in class. In this respect, Shumin suggested that speaking performance can be affected by affective factors, and motivation is one kind of affective factors affecting students' speaking performance [47].

Overall, the informants tend to hold positive attitude towards the benefits of OCF and they seem to view it crucial for learning the target language. The majority of the teachers seem to maintain the role of OCF in promoting accuracy and fluency. This perception can be an indicator of teachers' concern and focus on form and on meaning teaching.

\subsection{The Perceived Effects of OCF on EFL Learners in Terms of Their Affective Factors}

The following item is concerned with exploring teachers' perceptions regarding the possible effects of OCF on EFL learners' emotions and feelings during the learning process. The results to this question are displayed in the below table 3 .

Table 3. The perceived effects of OCF on EFL learners.

\begin{tabular}{|c|c|c|c|c|c|}
\hline & Completely disagree & Disagree & Partially agree & Agree & Completely agree \\
\hline OCF can be a factor of de-motivation & 0 & $85 \%$ & $15 \%$ & 0 & 0 \\
\hline OCF can be a factor of anxiety, shyness, and introversion. & 0 & $40 \%$ & $60 \%$ & 0 & 0 \\
\hline OCF can be a factor of annoyance. & $15 \%$ & $85 \%$ & 0 & 0 & 0 \\
\hline OCF can be an inhibitor of participation. & 0 & $40 \%$ & $35 \%$ & $25 \%$ & 0 \\
\hline
\end{tabular}

While $85 \%$ of the informants disagree that OCF can lead to learners' demotivation; (15\%) partially agreed with this view. It seems that the informants think that OCF cannot be a direct cause of frustration and demotivation. This perception emanates from the belief that OCF cannot damage learners' feelings or motivation to learn the target language since feedback providers can control and take into consideration the frequency of OCF delivery, learners' individual differences, students' personal traits, preferences and attitudes. In this case, OCF is not likely to be detrimental to the learning process or to the feelings and emotions of the students. Elsaghayer states "feedback should always be personal and never directed at person's personality" ([48], p. 76).

$60 \%$ of the participants partially agree that OCF can be a factor of anxiety, shyness, and introversion. This result obviously reveals a mismatch with the previously stated perception. The informants, who seem to be very concerned with learners' personality traits, preferences, and attitudes in order not to demotivate them, think that anxiety and shyness can be created in the process of OCF delivery. Therefore, it appears that there is not complete agreement among these teachers in this issue. Mostly the informants (85\%) disagree that OCF can be a factor of annoyance. They believe that EFL learners do not feel annoyed when provided with OCF. These teachers seem to care about learners' feelings and emotions.

The results show that $25 \%$ perceive that OCF inhibits students' participation in the classroom, 35\% partially agree with this view, and $40 \%$ disagree. This variation in the informants' responses can be linked to some other factors. First, teachers either "agree" or "partially agree" because they think that individual correction influences group correction, therefore it might hinder students' further participation. Second, it seems that the informants are concerned with the amount of OCF delivered as a factor affecting learners' participation. Third, these teachers seem to be aware of the importance of taking into account learners' varied attitudes and perceptions toward error correction while providing OCF. In the light of this reasoning, EFL teachers perceive OCF as a complex activity involving many intricate factors to manage thoughtfully in order not to prevent class participation.

\subsection{The Timing of Implementing $\mathrm{OCF}$}

When they were asked about their perceptions about the most appropriate time of conducting OCF, EFL teachers opted for either immediate correction or delayed correction. Table 4 displays the results of the informants' responses to this question.

Table 4. The timing of implementing $O C F$.

\begin{tabular}{|c|c|c|c|c|c|}
\hline & Completely disagree & Disagree & Partially agree & Agree & Completely agree \\
\hline Immediate correction & 0 & 0 & $45 \%$ & $55 \%$ & 0 \\
\hline Delayed correction & 0 & $75 \%$ & $35 \%$ & 0 & 0 \\
\hline
\end{tabular}

Regarding the distinction between immediate or delayed $\mathrm{CF}, 55 \%$ of the informants agree that teachers should provide
OCF just "immediately"; and 45\% "partially agree" with this statement. $75 \%$ of the participants "disagree" with the 
delayed correction, whereas 35\% "partially agree" with this view. This distinction in the informants' perceptions is basically related to the type of errors that should be corrected (general Vs. individual errors), as well as to the objective behind delivering OCF, that's to say if teachers want to focus on fluency, they will likely to opt for delayed CF and if they seek to promote accuracy, they will certainly choose immediate correction. Also, it seems that the participants who favor delayed correction take into account their students' affective dimensions; as such they do not want to disrupt or hinder students' conversational flow.

\subsection{The Types of Errors that OCF Should Target}

This part of the questionnaire intends to investigate perceptions of the participant teachers on error types that should be corrected through OCF. The results are displayed in the following table.

Table 5. The types of errors that OCF should target.

\begin{tabular}{|c|c|c|c|c|c|}
\hline & Completely disagree & Disagree & Partially agree & Agree & Completely agree \\
\hline Grammar & 0 & 0 & $15 \%$ & $45 \%$ & $40 \%$ \\
\hline Vocabulary & 0 & 0 & $20 \%$ & $50 \%$ & $30 \%$ \\
\hline Fluency & 0 & 0 & $85 \%$ & $10 \%$ & $5 \%$ \\
\hline
\end{tabular}

Table 5 shows a tendency to favor the correction of grammar errors as the majority of the respondents agree $(45 \%)$ or completely agree $(40 \%)$ with the view that $\mathrm{OCF}$ should target grammar errors. Similarly, a large proportion of the participants seem to prefer the correction of vocabulary related errors, as $50 \%$ of the informants agree and other proportion $(30 \%)$ completely agree with this perception. This result implies a strong tendency to favor the practice of focusing on form correction that is probably related to the nature of the classroom discourse and the types of activities endorsed in the classroom context.

In fact, the results show that while $85 \%$ of the respondents "partially agree" that OCF should target fluency errors and a proportion of $10 \%$ "agree" with this statement, $70 \%$ of the informants "partially agree" that OCF should focus on correcting pronunciation and a proportion of $15 \%$ "agree" and $15 \%$ "completely agree" with this view. It can be inferred, therefore, that fluency and pronunciation seem to gain little attention on behalf of the teachers and OCF seem to be directed toward grammar and vocabulary errors. Participant teachers perceive OCF as a necessary tool to make learners able to produce correct well-formed grammatical structures and to overcome language problems (form-focus teaching). In contrast, they do not show great concern to pronunciation and fluency errors.

\subsection{The Perceived Frequency of Conducting OCF During Oral Activities}

This section seeks to explore the frequency in which participant teachers deliver OCF during communicative activities. The informants' responses are displayed in the table below.

Table 6. The perceived frequency of conducting $O C F$ during oral activities.

\begin{tabular}{|c|c|c|c|c|c|}
\hline & Never & Hardly ever & Sometimes & Often & Always \\
\hline Grammar & 0 & 0 & 0 & $45 \%$ & $55 \%$ \\
\hline Vocabulary & 0 & 0 & $10 \%$ & $35 \%$ & $55 \%$ \\
\hline Fluency & 0 & 0 & 0 & $80 \%$ & $20 \%$ \\
\hline Pronunciation & 0 & 0 & $35 \%$ & $35 \%$ & $30 \%$ \\
\hline
\end{tabular}

Table 6 shows that teachers' responses are divided into two options "often" (45\%) and "always" (55\%) with regard to the correction of grammar errors. Most of the informants (55\%) also "always" care about their learners' vocabulary related errors. This implies a frequent concern with correcting grammar and vocabulary since they are interested in their learners' accuracy. This result confirms what was stated earlier concerning the types of errors that should be corrected through OCF. Yet, this perception clearly contradicts the spirit underlying CLT (the communicative approach) which aims to promoting learners' communicative skills through focusing on meaning negotiation and not on frequently correcting every single aspect of the language being studied, particularly grammar.

A proportion of $80 \%$ "often" and $20 \%$ "always" correct fluency errors. Regarding pronunciation, participants selected three options: (35\%) "sometimes", ( 35\%) “often" and (30\%) "always" deliver OCF to repair pronunciation problems. Teachers' interest in pronunciation and fluency is most likely related to their attempts to make their students able to pronounce the English language properly and fluently. As such, it seems that teachers show equal concern to their students' four aspects of speaking skills. However, this finding disapproves the result found in the previous item that highlighted the participants' disregard of fluency and pronunciation error types. This displays inconsistency in the informants' responses to the questions 5 and 6 .

\subsection{The Perceived Frequency of OCF Strategies Employed in the Classroom}

With regard to the frequently used type of OCF as a reaction to repair learners' spoken errors, the distribution of OCF types reported by the informants is depicted in table 7 . 
Table 7. The perceived frequency of OCF strategies used in the classroom.

\begin{tabular}{|c|c|c|c|c|c|}
\hline & Never & Hardly ever & Sometimes & Often & Always \\
\hline Elicitation & 0 & 0 & $20 \%$ & $35 \%$ & $45 \%$ \\
\hline Repetition & 0 & 0 & $50 \%$ & $30 \%$ & $20 \%$ \\
\hline Recats & 0 & 0 & $15 \%$ & $30 \%$ & $55 \%$ \\
\hline Clarification requests & 0 & 0 & $20 \%$ & $40 \%$ & $40 \%$ \\
\hline Explicit correction & 0 & 0 & $5 \%$ & $20 \%$ & $75 \%$ \\
\hline Metalinguistic cue & 0 & 0 & $15 \%$ & $50 \%$ & $35 \%$ \\
\hline
\end{tabular}

The results of table 7 show that participants remarkably varied their uses of CF types as a response to their students' spoken errors. All the teachers claim their use of $\mathrm{CF}$ strategies with different degrees of frequency as none of them opted for the options "never" or "hardly ever". The findings depict that explicit correction is the most favored type of CF which was reported to be used "always" by a proportion of $75 \%$ and "often" by a proportion of $20 \%$ of the informants. Recasts and Elicitation were mentioned next by respectively $55 \%$ and $45 \%$ of the participants who reported using them "always". Then, clarification requests was the type of CF "always" and "often" used by respectively $40 \%$ and $40 \%$ of the teachers; $20 \%$ of the informants claimed "sometimes" using this feedback type. Metalinguistic cue and repetition were the least frequented types of $\mathrm{CF}$ used by teachers in response to their students' spoken errors.

Overall, the informants' responses reveal that explicit correction and recasts are the frequently used corrective feedback strategies directed to correct and repair EFL learners' spoken errors. Elicitation is the third regularly employed type of $\mathrm{CF}$ followed by clarification request. Finally, metalinguistic cue and repetition are the least frequented strategies implemented by EFL teachers. This result also shows EFL teachers' tendency to prefer explicit correction strategies over implicit corrective feedback types.

\section{Conclusion}

The findings of this research study contributed to unveil the prevailing conceptions and views of EFL teachers regarding the concept of oral corrective feedback. EFL teachers hold positive attitudes towards $\mathrm{CF}$, as the majority of them believed in the benefits of OCF and its importance in the language learning process. Most of the participants tend to favor immediate correction over delayed correction. The majority of the teachers seem to maintain the role of OCF in promoting accuracy and fluency. Besides, the informants seem to care about learners' feelings and emotions since they mostly disagree about the statements that OCF can be a factor of demotivation, anxiety and annoyance. They seem to be aware of these factors while delivering feedback. However, the results display some discrepancy in teachers' responses to some items; for instance fluency and pronunciation gained little attention on behalf of the teachers and OCF is directed toward grammar and vocabulary errors. This frequent concern with correcting grammar and vocabulary emanates from teachers' interest in their learners' accuracy and focus-on form instruction. Explicit correction through explicit correction, recasts and elicitation is the most frequently employed corrective feedback strategies directed to remedy EFL learners' spoken errors. Metalinguistic cue and repetition, however, are the least frequented strategies used by the participants.

Finally, it worth mentioning that the current research is exploratory, as such future studies could be necessary to uncover any possible disparity between EFL teachers' perceptions about $\mathrm{CF}$ and their actual classroom practices during oral activities.

\section{References}

[1] Hattie, J. \& Timperley, H. (2007). The Power of Feedback. Review of Educational Research. March 2007, Vol. 77, No. 1, pp. 81-112.

[2] Crystal, D., \& Crystal, D. (2008). A dictionary of linguistics and phonetics. Malden, MA: Blackwell Pub.

[3] Leahy, S., Lyon, C., Thompson, M., \& Wiliam, D. (2005). Classroom assessment: minute by minute, day by day. Educational Leadership, 63 (3), 18-24.

[4] Brown, G. T. L., \& Harris, L. R. (2012). Student Selfassessment. In J. H. McMillan (Ed.). The SAGE Handbook of Research on Classroom Assessment (pp. xx-Xx). Thousand Oaks, CA: Sage.

[5] Shute, V. J. (2008). Focus on formative feedback. Review of Educational Research, 78 (1), 153-189.

[6] Chaudron, C. (1977). A descriptive model of discourse in the corrective treatment of learners' errors. Language Learning, 27, 29-46.

[7] Schegloff, E., Jefferson, G., \& Sacks, H. (1977). The Preference for Self-Correction in the Organization of Repair in Conversation. Language, 53 (2), 361-382. doi: 10. $2307 / 413107$.

[8] Lyster, R., Saito, K., \& Sato, M. (2013). Oral corrective feedback in second language classrooms. Language Teaching, 46 (1), 1-40.

[9] Lightbown, P. M. and Spada, N. (1999). How languages are learned? (2ND edition). Oxford. Oxford University press.

[10] Russell, J., \&Spada, N. (2006). The effectiveness of corrective feedback for the acquisition of L2 grammar. A meta-analysis of the research. In J. M. Norris, \& L. Ortega (Eds.), Synthesizing research on language learning and teaching (pp. 133-164). Philadelphia: John Benjamins.

[11] Ellis, R., Loewen, S., \& Erlam, R. (2006). Implicit and explicit corrective feedback and the acquisition of L2 grammar. Studies in Second Language Acquisition, 28, 339368 . 
[12] Carroll, S. (2001). Input and evidence: The raw material of second language acquisition. Amsterdam, The Netherlands: John Benjamins.

[13] Long, M. H., \& Robinson, P. (1998). Focus on form: Theory research, and practice. In C. Doughty \& J. Williams (Eds.), Focus on form in second language acquisition (pp. 15-41). Cambridge: Cambridge University Press.

[14] Schachter, J. (1991). Corrective feedback in historical perspective. Second Language Research.

[15] Gass, S. M. (1997). Input, Interaction, and the Second Language Learner. Mahwah, NJ. Lawrence Erlbaum.

[16] Richards, J. C., Platt, J., and Platt, H. (1992). Dictionary of language teaching and applied linguistics. London: Longman.

[17] Lyster, R. (2004). Differential effects of prompts and recasts in form-focused instruction. Studies in Second Language Acquisiti, 26, 399-432.

[18] Allwright, R. L. (1975). Problems in the study of the language teacher's treatment of error. In M. K. Burt \& H. D. Dulay (Eds.), New directions in second language learning, teaching, and bilingual education. Selected papers from the Ninth Annual TESOL Convention. Washington, D. C: TESOL.

[19] Ellis, R. (2012). Language teaching research and language pedagogy. Wiley- Blackwell.

[20] Moreno, R. (2004). Decreasing cognitive load for novice students: Effects of explanatory versus corrective feedback in discovery -based multimedia. Instructional Science, 32. 99113.

[21] Gass, S. and Selinker, L. (2008). Second language acquisition: An introductory course Third Edition). New York: Routledge.

[22] Dlaska, A. \& Krekeler, C. (2013). The short-term effects of individual corrective feedback on L2 pronunciation. System, $41,25-37$.

[23] Lyster, R and Ranta, L. (1997). 'Oral Corrective Feedback and Student Uptake; Negotiation of Form in Communicative Classrooms.'SSLA. pp. 44-55.

[24] Borg, S. (2006). Teacher cognition and language education: Research and practice. London: Continuum.

[25] Brown, G. T. L. (2008). Conceptions of assessment: Understanding what assessment means to teachers and students. New York: Nova Science Publishers.

[26] Thompson, A. G. (1992). Teachers' beliefs and conceptions: A synthesis of the research. In D. A. Grouws (Ed.), Handbook of research on mathematics teaching and learning (pp. 127-146). New York: MacMillan.

[27] Ajzen, I. (2005). Attitudes, personality and behavior (2nd ed). New York: Open University Press.

[28] Pajares, M. F. (1992). Teachers' beliefs and educational research: Cleaning up a messy construct. Review of Educational Research, 62, 307-332.

[29] Rubie-Davies, C. M., Flint, A., \& McDonald, L. G. (2011) Teacher beliefs, teacher characteristics, and school contextual factors: What are the relationships? British Journal of Educational Psychology, doi: 10.1111/j.20448279.2011.02025. x.
[30] Woolfolk Hoy, A., Davis, H., \&Pape, S. J. (2006). Teacher knowledge and beliefs. In P. A. Alexander \& P. H. Winne (Eds.), Handbook of educational psychology (2nd ed., pp. 715-737). Mahwah, NJ: LEA.

[31] Shinde, M. and Karekatti, T. (2012). Re-service teachers' beliefs about teaching English to primary school children. International Journal of Instruction, Vol. 5, No. 1, 69-86.

[32] Hsieh, H-J. \& Chang, S-J. (2002). Elementary school English teachers' beliefs about EFL learning. Selected Papers from the Eleventh International Symposium on English Teaching/ Fourth Pan-Asian Conference (Vol. 2, pp. 116-124). Taipei, Taiwan: Crane Publishing Co. Jersey: Prentice Hall.

[33] Johnson, K. E. (1992). Learning to teach: instructional actions and decisions of preservice ESL teachers. TESOL Quarterly, $26,507-535$.

[34] Kern, R. (1995). Students' and teachers' beliefs about language learning. Foreign Language Annals, 28 (1), 71-85.

[35] Liao, P. \& Chiang, M. (2003). The study of students' and teachers' beliefs about English learning. Proceedings of the 2003 International Conference on English Teaching and Learning in the Republic of China (pp. 65-76). Taipei, Taiwan: Crane Publishing Co.

[36] Yang, N-D. (2000). What do prospective teachers think about teaching English to children? Selected Papers from the Ninth International Symposium on English Teaching (pp. 556-565). Taipei, Taiwan: Crane Publishing Co.

[37] William, M., \& Burden, R. L. (1997). Psychology for language teachers: A social constructivist approach. Cambridge, U.K.: Cambridge University Press.

[38] Borg, S. (2003). Teacher cognition in language teaching: A review of research on what language teachers think, know, believe, and do. Language Teaching, 36, 81-109.

[39] Crookes, G. \& Arakaki, L. (1999). Teaching idea sources and work conditions in an ESL program. TESOL Journal, 8 (1), 15-19.

[40] Johnson, K. (2008). Precision Teaching. In N. Suskind (ed.), The Encyclopedia of Educational Psychology, 2, 809-813. Thousand Oaks, CA: Sage Publications.

[41] Torrance, H., \& Pryor, J. (1998). Investigating formative assessment: Teaching, learning and assessment in the classroom. Buckingham, UK: Open University Press.

[42] Tunstall, P., \& Gipps, C. (1996). Teacher feedback to young children in formative assessment: A typology. British Educational Research Journal, 22, (4), 389-404.

[43] Harmer, J. (1991). The practice of English language teaching. Longman Handbooks for Language Teachers. London/New York.

[44] Swain, M. (1985). Communicative Competence: Some roles of Comprehensible Input and Comprehensible Output in its Development. In S. Gass \& C. Madden (Eds.), Input in second language acquisition (pp. 235-253), Rowley, MA: Newbury House.

[45] Kosar, G. and Bedir, H. (2014). 'Strategies- Based Instruction: A means of Improving Adult EFL Learners' Speaking Skills.' International Journal of Language Academy, 2/3: 16-17. 
[46] Sarwar, M. Ashfaque, A. S. and Mehlah Jabeen. (2014). 'Assessing English Speaking Skills of Prospective Teachers at Entry and Graduation Level in Teacher.' Language Testing in Asia; A Springer Open Journal, 4/5: 1.

[47] Shumin, K. (2010). In Jack Richards and Willy A. Renandya (Ed.), Methodology in Language Teaching: An Anthology of
Current Practice. Cambridge: Cambridge University Press, pp. 205-206.

[48] Elsaghayer, M. (2014). 'Affective Damage to Oral Corrective Feedback among Students in Libyan Secondary Schools. IQSR Journal of Research \& Method in Education (IQSRJRME), 4/6: 76. 